\title{
Paradoxal relação da vida versus morte e a transfusão de sangue nas Testemunhas de Jeová
}

Paradoxical relationship of life versus death and blood transfusion in Jehovah's Witnesses

Paradoxal relación de la vida versus muerte y la transfusión de sangre en los Testigos de Jehová

Thaiana Cirqueira Gonçalves ${ }^{1}$

RESUMO: Objetivo - O presente trabalho visa estudar o conflito de princípios fundamentais na base de bioética e no ordenamento jurídico brasileiro. Metodologia - Foi feita uma revisão narrativa de literatura. Resultados - Pacientes que são vinculados / adeptos da religião "Testemunhas de Jeová" recusam tratamento de transfusão de sangue por motivo de suas crenças religiosas, contudo, é necessário respeitar o princípio da dignidade humana. $O$ tratamento com sangue para os adeptos da Testemunhas de Jeová é uma problemática complexa que envolve diferentes paradigmas e uma colisão de preceitos fundamentais, como a liberdade de crença e o direito à vida. Há um conflito entre a autonomia do paciente e o dever e responsabilidade civil do profissional de saúde. Para o tratamento alternativo, alguns métodos são oferecidos para mas o sangue não tem um substituto eficaz, sendo muitas vezes o único meio para se manter uma vida. Conclusão Há escassa literatura para o tema da transfusão de sangue em adeptos da Testemunhas de Jeová e as posições são antagônicas.

Palavras-chave: Transfusão de sangue. Testemunha de Jeová. Direito a Saúde

ABSTRACT: Objective - This study aims to study the conflict of fundamental principles based on bioethics and the Brazilian legal system. Methodology - A narrative review of the literature was done. Results: Patients who are "Jehovah's Witnesses" adherents refuse blood transfusion treatment for reasons related to their religious beliefs. This, in turn, underlies the life and principles that these people will follow, however, it is necessary to respect the principle of human dignity. Therefore, allogeneic blood treatment in Jehovah's Witnesses is a complex problem involving different paradigms and a collision of fundamental precepts such as freedom of belief and the right to life. The autonomy of the patient and the duty and responsibility of the health professional to save lives also come into conflict. For the alternative treatment some methods have been created with the intention of minimizing this problem, however, despite the numerous techniques to avoid transfusion, blood does not have an obsolete and effective substitute, it is often the only way to maintain life of the patient. Conclusion - There is little literature on the topic of blood transfusion among Jehovah's Witnesses.

Keywords: Blood transfusion. Jehovah's Witnesses. Right to Health

RESUMEN: Objetivo - El presente trabajo pretende estudiar el conflicto de principios fundamentales en la base de bioética y en el ordenamiento jurídico brasileño. Metodología - Se realizó una revisión narrativa de la literatura. Resultados - Pacientes que son

\footnotetext{
${ }^{1}$ Especialista em Direito Sanitário. Email: thaianaa@hotmail.com
} 
vinculados / adeptos de la religión "Testigos de Jehová" rechazan tratamiento de transfusión de sangre por motivo de sus creencias religiosas, sin embargo, es necesario respetar el principio de la dignidad humana. El tratamiento con la sangre para los adeptos de los Testigos de Jehová es una problemática compleja que involucra distintos paradigmas y una colisión de preceptos fundamentales, como la libertad de creencia y el derecho a la vida. Hay un conflicto entre la autonomía del paciente y el deber y responsabilidad civil del profesional de la salud. Para el tratamiento alternativo, algunos métodos se ofrecen pero la sangre no tiene un sustituto eficaz, siendo a menudo el único medio para mantenerse una vida. Conclusión - Hay escasa literatura para el tema de la transfusión de la sangre en adeptos de los Testigos de Jehová y las posiciones son antagónicas.

Palabras llave: Transfusión de sangre. Testigo de Jehová. Derecho a la Salud

\section{Introdução}

O conceito de saúde é dito como um estado de completo bem-estar físico, mental e social, ou seja, não apenas a ausência de doenças ou enfermidades (1). A saúde se torna então, um emaranhado de facetas que visa a busca da qualidade de vida de um ser humano, tornando-se algo de alta complexidade.

A saúde é um objeto de proteção jurídica, já que a Constituição Federal rege que a saúde é um dever do Estado e direito de todos. Portanto, proteger à saúde juridicamente, equivale à proteção estatal de todos os direitos e necessidades que visam garantir a saúde de cada indivíduo, seja por meio de ações, serviços ou intervenções tanto de caráter preventivo quanto curativo (2).

Segundo Mueller, Plevak e Rummans (3) a maioria dos pacientes têm alguma forma de vivência espiritual e, através da análise comparativa de estudos publicados sobre esta temática, entenderam que a espiritualidade e o envolvimento religioso estão associados com melhores prognósticos de saúde, incluindo maior longevidade, mais autonomia e melhor qualidade de vida.

A questão da recusa de pacientes adeptos a seita das "Testemunhas de Jeová" à transfusão de sangue por motivos religiosos é um assunto bastante polêmico. Esta situação envolve um confronto entre as crenças e a autonomia do paciente e o dever e responsabilidade do profissional de saúde em salvar vidas. Na situação em que um paciente recusa o tratamento à base de sangue e seu médico insiste nele, surge um conflito, que precisa ser solucionado pelos princípios da bioética e do ordenamento jurídico vigente, especialmente os princípios fundamentais. 
Assim, a pretensão desse trabalho é analisar a paradoxal relação da transfusão de sangue com a dignidade humana, no que concerne à autonomia do sujeito e o dever do médico, observando os limites dessa situação, com vistas, também, ao paradigma religioso envolvido nessa discussão. Destarte, o trabalho tem o intuito de, através da bioética e de um levantamento bibliográfico sobre a temática, apresentar o estado da arte dessa discussão numa perspectiva crítica.

\section{Metodologia}

No que concerne à metodologia, foi realizado um levantamento bibliográfico, a partir de sites de buscas de artigos científicos, tais como Medline, PsycINFO, Bireme, Scielo. O filtro para a busca foram os seguintes descritores: transfusão de sangue; liberdade de crença; testemunhas de Jeová; bioética; autonomia do paciente.

Foram utilizadas, ainda, as referências bibliográficas de doutrina conceituada para se aprofundar sobre a temática e realizar um estudo detalhado. No que tange ao método de análise, pode-se dizer que serão utilizados alguns aportes da bioética, tais como a autonomia do paciente e a dignidade humana.

O trabalho foi dividido em três aspectos relevantes. Inicialmente contextualizaremos a transfusão de sangue, sua eficácia e métodos alternativos, além de uma análise sobre a religião das "Testemunhas de Jeová" para uma maior compreensão dessa crença. Posteriormente, o tema abordado será a bioética fundamentada nos princípios basilares da Constituição Federal sobre esse dilema. Por fim, abordaremos o paradoxo entre a vida em relação a uma morte digna segundo a crença da religião em questão, o dilema do corpo médico entre sua responsabilidade de salvar vidas e a autonomia do paciente e os contextos nos quais esse dilema é ainda mais complexo.

\section{Resultados}

A transfusão de sangue é uma importante ferramenta para o tratamento de suporte que auxilia na reposição de volume sanguíneo ou para corrigir o déficit de alguns componentes sanguíneos. Todavia, para se minimizar os riscos oriundos da transfusão alogênica e em situações de recusa do paciente ao tratamento como é o caso das Testemunhas de Jeová, outras técnicas foram disponibilizadas tentando ser uma alternativa para obter a cura sem a utilização de sangue. Será abordada a eficácia da 
transfusão sanguínea e dos métodos alternativos, além de uma contextualização sobre as testemunhas de Jeová para se entender a recusa da terapia com sangue. Analisaremos, nos tópicos seguintes, o método tradicional e os alternativos, no que concerne à transfusão de sangue, bem como as suas eficácias.

Até cerca de 1900, a transfusão sanguínea era uma atividade empírica. Após a descoberta dos grupos sanguíneos por Karl Landsteiner, o diagnóstico e tratamento hemoterápico ganharam espaço como uma prática científica (4).

Os hemocomponentes e hemoderivados têm papel importante dentro dos tratamentos médicos. As transfusões com sangue são realizadas para aumentar a capacidade do sangue de transportar oxigênio, para restaurar o volume sanguíneo do organismo, para melhorar a imunidade ou para corrigir distúrbios da coagulação (5).

Porém, pacientes Testemunhas de Jeová se recusam, terminantemente, a receber transfusão sanguínea, ainda que autólogas com sangue previamente armazenado. Esses pacientes defendem a tese de que ao invés da hemotransfusão, método tradicional para tratamento de suporte, podem-se utilizar métodos alternativos como eritropoietina humana recombinante, interleucina-11 recombinante, ácido aminocapróico e tranexâmico, adesivos teciduais, expansores do volume do plasma, colóides e instrumentos hemostáticos como o eletrocautério, lasers ou o coagulador com raio de argônio (6).

Em 6 de outubro de 1998 foi realizada uma conferência médica internacional em Moscou, intitulada "Alternativas para Transfusões nas Cirurgias", na qual compareceram cerca de 800 médicos de diversas localidades como Rússia, França, EUA, Bélgica e Suécia. A partir dessa conferência as Testemunhas de Jeová iniciaram a busca por métodos alternativos e reiteraram o seu entendimento quanto ao fato de que escolheriam outro método para o tratamento de saúde que demandasse transfusão. Assim, observa-se que essa conferência foi um marco histórico para essa problemática (7).

Com a recusa das Testemunhas de Jeová para tratamento com sangue, buscaramse métodos alternativos de tratamento, sendo que a decisão de aceitar ou não o tratamento é escolha exclusiva de cada paciente Testemunha de Jeová. Ou seja, a autonomia do indivíduo, no tocante à escolha do seu tratamento, é o "novo" paradigma.

Algumas metodologias para a substituição de sangue são utilizadas, por exemplo, líquidos expansores eficazes do volume do plasma, que não contêm sangue, para a compensação de perda sanguínea, entre eles, a solução salina, dextrama, o haemacel, a 
solução de lactato de Ringer e a hidroxietila de amido. Para a compensação de oxigênio, os médicos podem ministrar oxigênio em concentração alta, depois de recuperado o volume plasmático e, também, podem ajudar a formar mais glóbulos vermelhos, ministrando concentrados de ferro e a eritropoietina sintética (8).

A transfusão autóloga é a técnica de transfusão que utiliza o próprio sangue armazenado previamente antes de cirurgias eletivas para reposição posterior, porém esta técnica não é aceita pelas Testemunhas de Jeová. Nesses pacientes pode-se utilizar a técnica de hemodiluição normovolêmica aguda, que consiste na retirada de um volume previamente determinado de sangue e reposição simultânea de solução cristalóide, colóide ou ambos, não sendo separado do paciente e reinfundido durante ou no final da cirurgia (9).

Existe também, o sistema de recuperação das células sanguíneas durante a cirurgia. A máquina de autotransfusão recebe o sangue coletado do paciente, por meio de sucção durante a cirurgia, misturando-o com solução fisiológica, separando as hemácias e removendo as impurezas. Essas células sanguíneas são então reinfundidas no paciente, sendo um procedimento (a reinfusão) contínuo à conexão do sangue com o paciente (9).

Há a possibilidade de se resfriar o paciente durante a cirurgia para reduzir as necessidades de oxigênio, ou ainda utilizar bisturi elétrico nesses procedimentos para se minimizar os riscos de hemorragias. Porém essas técnicas que minimizam a perda de sangue, não possuem eficácia suficiente para reverter certos quadros (8).

Entretanto, apesar das inúmeras técnicas para se evitar a transfusão, o sangue não tem um substituto obsoleto e eficaz. Em pacientes com iminente perigo de vida, a realização de transfusão de sangue seria imprescindível para restabelecer o volume intravascular e restaurar a capacidade de transporte de oxigênio em tempo adequado, não podendo, atualmente, ser suprida por alternativa médica. A decisão de transfundir componentes do sangue deve ser avaliada, contrabalançando seus riscos e benefícios (10).

As Testemunhas de Jeová têm um contingente de adeptos de aproximadamente 7.000.000 pessoas distribuídas em 236 países, segundo as informações da Sociedade Torre de Vigia de Bíblias e Tratados, atualizados em 2012. A religião tem costumes peculiares e interpretações próprias dos textos bíblicos. Entre uma de suas crenças, está a 
da condenação pelo recebimento de sangue de outra pessoa, logo não recebem o tratamento de transfusão sanguínea.

Um dos fundamentos da religião (e que, por sua vez, justificam a proibição em relação à transfusão de sangue) está calcado na interpretação dos seguintes trechos bíblicos:

Tudo o que se rasteja e que vive vos servirá de alimento, bem como a erva que amadurece; eu vos dou tudo. Todavia não comereis carne com vida, isto é, o seu sangue $(\mathrm{Gn}$ 9:3,4).

Se um homem da casa de Israel ou dos migrantes que aí moram consumir sangue, voltar-me-ei contra o que tiver consumido o sangue, para cortá-lo do meio do seu povo (Lv 17: 10).

Com efeito, parece bem ao Espírito Santo e a nós não vos impor outro peso além do seguinte indispensável: que vos abstenhais das carnes sacrificadas aos ídolos, do sangue, da carne sufocada e da impureza. Dessas coisas fareis bem de vos guardar conscienciosamente (Atos 15:28, 29).

O povo completamente exausto se atirou sobre os despojos. Lançou mão das ovelhas, bois e bezerros, os degolou no chão e comeu em cima do sangue. Contaram a Saul: o povo, disseram, está pecando contra o Senhor, ao comer em cima do sangue (1Sm 14:32,33).

Decidem então, não utilizar o sangue alogênico, seja pela via oral, seja pela via venal, esta questão envolve princípios que como cristãos, fundamentam sua vida.

Em que pese haja essa interpretação e proibição, os crentes nesse dogma religioso deparam-se constantemente com conflitos relacionados à comunidade médica, no que tange a dar a assistência de que necessitam. As Testemunhas de Jeová aceitam a maioria dos tratamentos médicos e procedimentos cirúrgicos disponíveis. Nos casos nos quais não aceitam, buscam métodos alternativos. Por essas razões, dispõem de um Serviço de Informações sobre Hospitais e as Comissões de Ligação com Hospitais (COLIHs), sob direção do Corpo Governante das Testemunhas de Jeová, com o intuito de apoiar os pacientes e fornecer ao corpo clínico informações sobre métodos alternativos às transfusões sanguíneas, para que o paciente seja atendido de acordo com suas convicções, porém tendo um tratamento adequado. Essas organizações visam minimizar os conflitos entre comunidade médica e esta classe de pacientes (11).

Além disso, passaram também a utilizar um cartão com a seguinte observação escrita "Documento para Uso Médico", que tem o intuito de alertar o profissional de saúde que não aceitam, em nenhuma circunstância, a utilização de transfusão de sangue, entretanto aceitam métodos alternativos. O cartão tem a assinatura do titular e de 
testemunhas, geralmente parentes próximos. O cartão tornou-se um documento "legal", conforme o entendimento dos doutrinadores da área jurídica e da saúde (8).

É válido destacar que as Testemunhas de Jeová assinam um termo de responsabilidade isentando médicos e hospitais da responsabilidade civil ao se ausentarem da utilização do sangue como tratamento (8). Afirmam que por mais que morram pela falta de tratamento com o sangue, confiam nas promessas divinas: "Deus não se esquece dos que lhe são fiéis e Ihes restituirá a vida por meio da ressurreição. Para Essas pessoas, o mais importante, e que está acima de tudo, é o desejo de agradar a Deus" (Atos 24:15).

Esse termo de responsabilidade é questionável, não só pelo direito, mas, também, pela Bioética, tendo em vista que o paciente não está em condições de escolher ou deliberar sobre isso.

A reivindicação da autonomia do paciente na escolha de aceitar ou não alguns tratamentos, busca na bioética solução para essa problemática do paternalismo médico (11).

A bioética é a união do conhecimento biológico e valores humanos para se atingir uma nova sabedoria (12). É uma ética aplicada, com o intuito de utilizar corretamente tecnologias na área das ciências médicas e da solução adequada dos dilemas morais por elas apresentados (13).

Quando a discussão gira em torno da dignidade do indivíduo durante a sua vida, inclusive na situação de doença ou de morte, envolvendo a valorização das suas necessidades particulares e a diminuição do seu sofrimento, devem ser considerados princípios bioéticos. Cada pessoa deve ter suas necessidades atendidas reconhecendo-se as diferenças e as singularidades destas (14), (15).

A medicina ocidental tinha como postura sobre esse tema, principalmente quando envolve um caráter religioso, de se desconsiderar tais necessidades por admitirem que esses assuntos sejam sem importância ou por não fazerem parte do tema principal, a saúde (16). Todavia, artigos científicos evidenciam uma associação entre a religião e a saúde, mostrando um benefício na programação terapêutica quando explorada a espiritualidade (17).

No processo de tomada de decisão, o sistema de crenças de uma pessoa tem papel fundamental, pois o caráter religioso atinge a sua percepção e os princípios escolhidos 
para a vida, o conjunto das alternativas disponíveis e a seleção da ação que irá ser realizada diante da situação problema. Os aspectos religiosos devem ser observados através de uma reflexão bioética, sempre preservando a impessoalidade e a imparcialidade da discussão (18).

Quando há conflitos entre a vida e a liberdade de crença, na tomada de decisão perante a escolha de tratamentos se levam em consideração a possibilidade de se perder a vida, estamos diante de um dilema. Nessa tomada de decisão não podemos esquecer de que a vida está intimamente ligada a outros princípios, tais como o da dignidade da pessoa humana, ou seja, excluir a importância das crenças nessa tomada de decisão pode até preservar a vida biológica, entretanto, pode levar o indivíduo a morte social.

A liberdade de crença é o direito de escolher a sua religião, não se resumindo apenas em o Estado não impor religião ou impedir alguma, mas também em permitir ou propiciar a quem seguir alguma religião, o cumprimento dos deveres que decorre desta religião, em sua razoabilidade, e, o Estado não impor ou garantir com as leis, o cumprimento desses deveres (19). Já a liberdade de culto é a exteriorização da prática religiosa, como por exemplo, os ritos, as manifestações, reuniões, cerimônias, hábitos religiosos seja em domicílio ou em público (8). A liberdade religiosa é um direito de primeira geração, sendo uma forma de manifestação do pensamento (20).

Entre um conflito que envolva o direito à vida e o direito à liberdade, quem deve escolher o que irá prevalecer é o próprio titular desses direitos, apesar de que manter a liberdade pode acarretar um grave risco de morte, e por mais paradoxal que seja para alguns preferir a morte à perda da liberdade, deve ser respeitada a escolha (21).

Reforçando essa ideia, em casos específicos de Testemunhas de Jeová, a jurisprudência internacional tem entendido que se deve respeitar a vontade do paciente, independente dos riscos dela decorrentes (19). Os riscos advindos da recusa devem ser explicados de forma clara para o total entendimento do paciente e a escolha deve caber a ele próprio, o princípio da autonomia deve ser respeitado juntamente com a sua escolha de crença e valores.

Se existirem situações que impeçam o indivíduo de praticar a religião, apesar de Ihes concederem o direito de ter uma religião, nesse caso estará sendo violentado o direito à liberdade religiosa. (8). A religião que a pessoa determinou seguir e conduzir a sua vida deve ser respeitada em todos os momentos de sua existência, independente de local ou 
situação. Pois se assim não ocorrer não estaria sendo acatado o direito à liberdade de crença, e sim, somente uma proteção aos locais de culto e suas liturgias (22).

Apesar disso, não existe uma conclusão genérica sobre tal problemática. Todos os casos devem ser analisados conforme as provas e circunstâncias de cada situação.

A dignidade humana é uma condição para a vida. Nesse sentido, a Carta Magna alude que: "Todos são iguais perante a lei, sem distinção de qualquer natureza, garantindo-se aos brasileiros e aos estrangeiros residentes no País a inviolabilidade do direito à vida, à liberdade, à igualdade, à segurança e à propriedade [...]" (23).

Um dos direitos fundamentais invioláveis é o direito à vida. A vida é considerada como um bem maior, de suma relevância, constitui-se em pré-requisito à existência dos demais direitos (23). Por isso é que ela constitui a fonte primária de todos os outros bens jurídicos (24).

A vida é um estado bem mais complexo do que meramente em sentido biológico, é algo dinâmico que se transforma constantemente. Integra-se de elementos materiais, físicos e psíquicos, e, imateriais, espirituais. Devido a esses elementos que a incorporam, envolvem em seu conceito outros direitos, como o direito à dignidade humana, direito à privacidade, direito à integridade físico-corporal, direito à integridade moral, entre outros (24).

A dignidade, por sua vez, é um valor espiritual e moral inerente à pessoa, remete ao anseio pelo respeito para consigo. O direito à vida privada, à intimidade, à honra, à imagem, dentre outros, aparece como consequência imediata da consagração da dignidade da pessoa humana, e o Estado deve impetrar métodos para assegurar tal princípio (24).

Não basta ao Estado somente reconhecer formalmente todos estes princípios, principalmente o da dignidade humana; deve buscar a concretização e o pleito destes diariamente na vida, em todas as circunstâncias, de cada indivíduo (25). Segundo Sarlet (26), a contemplação dos direitos fundamentais, de forma geral, é a concretização das exigências necessárias do princípio da dignidade da pessoa humana, é o valor diretório para toda a ordem jurídica.

Sem respeitar o princípio da dignidade humana não há como se respeitar também o direito à vida, pois eles estão intimamente ligados. Para haver dignidade é necessário a vida. Um indivíduo sem sua dignidade, sem a possibilidade de necessidade prevalecer 
suas crenças, sua honra e hombridade não conseguirá viver de forma íntegra, terá seu respeito para consigo mesmo manchado e não conseguirá contemplar a vida, ou seja, não podemos considerar isso viver, logo estará ferindo também o direito à vida.

A escolha das Testemunhas de Jeová por receber tratamento sem sangue está respaldada pelo direito à autonomia do paciente, pelo princípio da dignidade humana e pela liberdade de crença, porém existe um conflito de valores entre o paciente e o corpo médico, o qual tem o dever de socorrer e manter a vida do paciente, utilizando todas as ferramentas cabíveis para se conseguir tal feito. Esse dever está contemplado, a priori, pela Constituição Brasileira que contempla o direito à vida. Esse embate, em vários casos tem perspectivas diferentes, os quais serão detalhados a seguir.

A recusa de tratamento por transfusão sanguínea em Testemunhas de Jeová é uma questão polêmica em vários âmbitos. Estão inseridos nesta contextualização os profissionais de saúde com a sua responsabilidade de prestar o socorro e sua responsabilidade de salvar vidas; do outro lado está o paciente com seu direito à autonomia, à liberdade de crença e à sua dignidade.

Essa problemática gera conflitos entre beneficência e autonomia do paciente em relação à escolha do tratamento. Alguns profissionais da saúde não admitem a recusa da transfusão sanguínea, baseando-se na sua responsabilidade civil de promover o socorro e salvar vidas, dando prioridade ao direito à vida. Outra classe preconiza os métodos alternativos e só utiliza a transfusão sanguínea quando há risco iminente de vida, sempre levando em consideração o paradigma do risco e do benefício, porém, em certos casos, postergar o tratamento sanguíneo pode agravar o quadro do paciente, não havendo mais alternativas (8).

A palavra autonomia é derivada do grego autos (próprio) e nomos (regra, governo, lei), logo, refere-se à possibilidade de autogovernamentação, ou seja, gerir sobre os direitos de liberdade, escolhas individuais, privacidade, direito do indivíduo de tomar decisões alusivas à sua própria vida. Nesse mérito, questões que envolvam sua saúde, sua integridade físico-psíquica, suas relações sociais envolvem o princípio da autonomia (27). Podemos dizer que a pessoa autônoma é aquela que tem liberdade de pensamento, é livre para decidir entre as escolhas que são oferecidas, decidindo o que é melhor para si (28). Já o princípio da beneficência é a obrigatoriedade moral de agir em benefício de outrem, está baseado na obrigação de ajudar outras pessoas promovendo o bem (27). 
É com base no princípio da beneficência que o corpo médico tem a obrigação de promover o melhor para o seu paciente. Quando se insiste na transfusão de sangue, mesmo quando o paciente se recusa aceitar o procedimento da transfusão, o profissional de saúde apenas está na busca de tentar proporcionar o melhor para seu paciente. Logo, nos casos de pacientes Testemunhas de Jeová ocorre o choque desses dois princípios, o da autonomia do paciente e a beneficência do médico.

Respeitar a autonomia do paciente é reconhecer que cabe ao indivíduo tomar decisões sobre o seu plano de vida, embasado em suas crenças e valores íntimos, mesmo quando for divergente daquelas que dominam a sociedade e das crenças dos profissionais de saúde, exceto quando possam gerar ameaça a outrem ou à coletividade. Deve-se lembrar de que a orientação e o esclarecimento devem ser dados pelo médico, porém o corpo, a dor, a doença e a vida são propriedades da pessoa, cabendo à mesma decidir segundo o princípio da autonomia (28).

O Código Penal dispõe no seu artigo 135 que comete crime de omissão quem "deixar de prestar assistência, quando possível fazê-lo sem risco pessoal, à criança abandonada ou extraviada, ou à pessoa inválida ou ferida, ao desamparo ou em grave e iminente perigo; ou não pedir, nesses casos, o socorro da autoridade pública", ainda, em seu parágrafo único, diz que "a pena é aumentada de metade, se da omissão resulta lesão corporal de natureza grave, e triplicada, se resulta a morte" (29).

A omissão de socorro é crime, entretanto, quando o médico opta por utilizar outras alternativas em relação à transfusão não significa que ele deixou de prestar assistência, não havendo assim negligência, imperícia ou imprudência, não haverá objeto para a responsabilidade civil. As Testemunhas de Jeová assinam um Termo de Isenção de Responsabilidade, pelo fato de se recusarem ao tratamento sanguíneo, logo, em tese não há responsabilidade do médico por falta ética ou omissiva, pois se deduz que o médico não tenha cometido a falta, levando em consideração a invocação do direito fundamental à liberdade (21).

De acordo com a Constituição Federal de 1988, artigo 5, II: "ninguém pode ser obrigado a fazer ou deixar de fazer alguma coisa senão em virtude de lei", segundo o Código Penal, artigo 146, comete o crime tipificado quem violar o direito prescrito no artigo $5^{\circ}$. Todavia, conforme está prescrita no parágrafo $3^{\circ}$ inciso I do mesmo a "intervenção médica ou cirúrgica, sem o consentimento do paciente ou de seu representante legal, se 
justificada por iminente perigo de vida", por esse motivo entende-se que quando o paciente se recusa a realizar transfusão sanguínea, primeiramente, deve-se analisar o riscobenefício da transfusão, se está for de suma necessidade para manutenção da vida, então, caso positivo, deverá realizar o tratamento mesmo com a recusa do paciente. Entretanto, quando essa terapia for por motivo de conveniência, não deverá ser realizada prevalecendo aqui, a vontade do paciente (19).

O Código de Ética Médica no seu capítulo I nos diz que "O alvo de toda a atenção do médico é a saúde do ser humano, em benefício da qual deverá agir com o máximo de zelo e o melhor de sua capacidade profissional" (30). O respeito à vida é um dos maiores princípios da ética médica, porém suas atitudes profissionais devem-se habituar às condições sociais vividas pelo paciente (31).

Todavia, em casos de ausência de algum representante, o médico age com a presunção do consentimento do paciente de lhe salvar a vida, já que sem o consentimento legal, estaria o médico impondo um tratamento e não permitindo a autonomia do paciente de dispor sobre o próprio corpo (31).

Mas somente haverá exclusão da ilicitude de uma intervenção médica sem o consentimento do paciente em situações de iminente perigo de vida, que seja imprescindível em razão de extrema urgência, que se constitua o único meio viável para salvar a vida do paciente. Existindo outro meio de tratamento deverá ser realizada opção eleita pelo enfermo, caso contrário estará o médico violando o direito do indivíduo de decidir o melhor para si. O Código de Ética Médica afirma o que foi citado acima nos artigos 46, "Efetuar qualquer procedimento médico sem o esclarecimento e consentimento prévios do paciente ou de seu responsável legal, salvo iminente perigo de vida", e no artigo 57, "Deixar de utilizar todos os meios disponíveis de diagnóstico e tratamento a seu alcance em favor do paciente" (30).

Porém, ainda existem alguns doutrinadores que acreditam que a interpretação literal destes artigos é absurda e incoerente, já que mesmo o paciente em iminente perigo de vida não perdeu o direito à liberdade. Afirmam que o dever do médico é de fonte legal e o direito do paciente de aceitar ou recusar um tratamento é expressão da sua liberdade (31).

De acordo com o artigo $3^{\circ}$ inciso I e artigo $4^{\circ}$ inciso I, do Código Civil de 2002, são absolutamente incapazes de exercer pessoalmente os atos da vida civil os menores de dezesseis anos e relativamente incapazes a certos atos, ou à maneira de exercê-los, os 
maiores de dezesseis anos e menores de dezoito anos. No artigo 1630 do Código Civil ainda rege que: "Os filhos estão sujeitos ao poder familiar, enquanto menores" (33).

No mesmo Código o artigo 1.634, V, reforça que: "Compete aos pais, quanto à pessoa dos filhos menores: representá-los, até aos dezesseis anos, nos atos da vida civil, e assisti-los, após essa idade, nos atos em que forem parte, suprindo-lhes o consentimento" (33).

Portanto, cabe ao poder familiar representar o paciente menor de idade, e assim realizar o direito de autonomia e escolha no tratamento médico. Se os pais decidem pela recusa de transfusão de sangue em seu filho, ainda que se tenham indicações médicas, em razão de suas convicções religiosas, princípios e valores familiares, deve a sua vontade ser respeitada, pois estão exercendo o seu direito de autonomia e da liberdade religiosa.

A recusa dos pais Testemunhas de Jeová ao tratamento sanguíneo nos pacientes menores de idade é constante. Quando ocorre um desfavor do corpo médico a posição manifestada pelos pais, considerando tal decisão como abuso do poder familiar, 0 profissional visando à vida do menor deve recorrer ao Poder Judiciário para a autorização do tratamento (31).

A jurisprudência dos Estados Unidos para outorga de autorização nestes casos utiliza o conceito de que o tratamento médico é necessidade básica para se manter a vida. O Estado por sua vez tem o deve de garantir à criança necessidades básicas, sendo uma delas a saúde e tratamento médico, logo o juiz pode determinar que o menor seja tratado.

Em nosso país, a fim de integrar as diversas disposições legais e normativas, consideramos que atualmente, em caso de emergências aonde há recusa ao tratamento pelo representante legal, o médico deverá intervir oponente ao consentimento do representante recorrendo ao Judiciário para solucionar o conflito.

Porém devemos ressaltar ainda, que o Estatuto da Criança e do Adolescente no artigo 15 nos diz: "A criança e o adolescente têm direito à liberdade, ao respeito e à dignidade como pessoas humanas em processo de desenvolvimento e como sujeitos de direitos civis, humanos e sociais garantidos na Constituição e nas leis". Reforça ainda no seu artigo 16 incisos II e III, o direito da criança de opinião e expressão, e, crença e culto religioso. Assim sendo, o tratamento médico, sempre que possível deve ser ouvir na medida da sua maturidade (34). 
Quando questionado sobre a sua decisão de recusa de tratamento com sangue nos filhos, as Testemunhas de Jeová solicitam a aplicação da "teoria do menor amadurecido". O menor amadurecido é aquele dotado de capacidade de fazer decisões, independentes, que conseguem entender a natureza e as consequências do tratamento proposto, e podem exercer seus próprios direitos, inclusive aqueles relacionados à personalidade (35).

Porém deixar prevalecer a vontade dos pais Testemunhas de Jeová em situações onde a vida do paciente menor está em risco, não sendo este um menor amadurecido, pode ser considerado abuso do direito à liberdade de crença e religião, levando-se em conta que se trata da vida de um terceiro que ainda não tem a capacidade de aderir a um grupo religioso e ainda não definiu seus valores como ser humano. Até mesmo para menores ditos amadurecidos é questionável a amplitude da responsabilidade da decisão, a qual, apesar de terem grau de entendimento, muitas vezes não compreende a dimensão da situação.

Segundo o Estatuto do Idoso regido pela a Lei 10471 de outubro de 2003, no seu artigo 17, "Ao idoso que esteja no domínio de suas faculdades mentais é assegurado o direito de optar pelo tratamento de saúde que lhe for reputado mais favorável". Ou seja, o idoso em situações de consciência mental está apto a manifestar sua vontade após devidamente orientado pelo médico e tem o direito de exercer o princípio da autonomia do paciente (36).

Vale salientar que este artigo não especifica as condições clínicas do paciente, sendo assim, mesmo em estados graves o idoso no domínio de suas faculdades mentais pode optar pelo tratamento médico que receberá (35). Todavia, o parágrafo único deste mesmo artigo rege a conduta nos casos em que o idoso não está facultado de suas condições mentais:

Não estando o idoso em condições de proceder à opção, esta será feita: I pelo curador, quando o idoso for interditado; II - pelos familiares, quando o idoso não tiver curador ou este não puder ser contactado em tempo hábil; III - pelo médico, quando ocorrer iminente risco de vida e não houver tempo hábil para consulta a curador ou familiar; IV - pelo próprio médico, quando não houver curador ou familiar conhecido, caso em que deverá comunicar o fato ao Ministério Público (36).

Nas condições de incapacidade mental do paciente idoso quem responderá pela autonomia do paciente será o curador ou familiar, em casos de faltarem às representações 
citadas acima se admite a intervenção do médico assistente com o objetivo de se salvar a vida do paciente.

Com o advento do avanço científico e tecnológico na medicina e até mesmo da qualidade de vida das pessoas, se estendeu a perspectiva de vida dos indivíduos acarretando a cada dia um maior número de pacientes idosos internados em hospitais. Muitas vezes os pacientes não estão em condições mentais para fazer quaisquer opções passando para seu responsável legal. Como a autonomia do paciente se tornou uma conquista dos direitos civis, a nova relação médico-paciente levou a tornar certas condutas obrigatórias, como a obrigatoriedade do Consentimento Informativo livre e esclarecido de fácil compreensão escrito pelo corpo médico explicando minuciosamente o tratamento de escolha para a enfermidade (37).

Esta conduta está descrita na Lei de Transplantes de Órgãos e Tecidos 9434 de fevereiro de 1997 no seu artigo 10, com a redação dada pela Lei 10211 de março de 2001: "O transplante ou enxerto só se fará com o consentimento expresso do receptor, assim inscrito em lista única de espera, após aconselhamento sobre a excepcionalidade e os riscos do procedimento" (38).

O sangue é um tecido líquido, logo, é necessário o consentimento assinado pelo responsável legal ou paciente facultado de suas condições mentais, este ato reforça também a autonomia do paciente que pode recusar-se a receber a transfusão de sangue (35). A recusa também está protegida pelo artigo $5^{\circ}$ inciso II da Constituição Federal, "ninguém será obrigado a fazer ou deixar de fazer alguma coisa senão em virtude de lei", em resumo, cada indivíduo só não fará aquilo que a lei proíbe (23).

Um tratamento imposto pelo corpo médico, especificamente uma transfusão sanguínea, realizada sem autorização, mesmo que para benefício do paciente, o médico estará praticando crime de constrangimento ilegal (38).

\section{Conclusão}

O tratamento com sangue alogênico em Testemunhas de Jeová é uma problemática complexa que envolve diferentes paradigmas e uma colisão de preceitos fundamentais. De um lado está o direito imensurável à vida e, de outro, o direito de expressar sua liberdade religiosa e por meio desta ter o direito de recusar tratamento médico por suas 
convicções de valores e princípios. Todos os dois princípios fundamentais estão igualmente amparados pela Constituição Federal Brasileira.

O tratamento tradicional para reposição de volume sanguíneo ou para corrigir o déficit de alguns componentes sanguíneos é a transfusão alogênica, a qual tem a melhor eficácia, entretanto, com a recusa das Testemunhas de Jeová houve a necessidade de se buscar métodos alternativos para suprir a necessidade de cura sem o uso de sangue. Todavia, apesar de todos os métodos alternativos já encontrados ainda não há substituto totalmente equivalente ao sangue, sendo a hemotransfusão algumas vezes, o único meio para se salvar a vida do paciente.

É essencial levarmos em consideração, sempre, o respeito pelas individualidades e necessidades do paciente. As Testemunhas de Jeová, por convicção religiosa, não aceitam esse tipo de tratamento. Assim, caso se realize a transfusão os valores e crenças seriam maculados, e, consequentemente, o princípio da dignidade da pessoa humana também.

Métodos alternativos devem, quando possível, ser utilizados e, em último caso, deve-se levantar a possibilidade de transfusão sanguínea. Antes de se tomar qualquer decisão sobre o tratamento de escolha, deve-se ter o consentimento do paciente, respeitando sua liberdade de crença e sem ferir a sua autonomia no que tange à escolha, pois a decisão final cabe ao paciente, tendo em vista que conforme seus princípios e valores ele decidirá sobre seu próprio corpo e sobra a sua vida. Deve-se enxergar o paciente como um todo e não somente como um ser biológico, pois para a existência de um indivíduo é necessário mais do que somente a vida propriamente dita, necessitamos de uma vida na qual a dignidade seja valorada.

Sobretudo, a vida é um bem inenarrável o qual deve ser preservado. Tal paradigma sustenta o dever do médico no que tange à responsabilidade de salvar vidas, porém, ao mesmo tempo ele deve respeitar o indivíduo como ser humano, especialmente no que diz respeito aos seus preceitos, aos valores atrelados à dignidade e principalmente seu direito de expressão, como demonstração de suas crenças e valores. O profissional deve, antes de qualquer tomada de decisão do paciente, explanar sobre a real situação da saúde do enfermo, os tratamentos e os riscos pela recusa do tratamento e, se permitido, deve entregar o consentimento livre esclarecido para a autorização do tratamento. Logo, o profissional deve respeitar e não impor sua realidade em relação à do paciente, mesmo 
que não concorde ou não acredite em seus valores, a opção terapêutica preferida pelo médico não prevalece à vontade do paciente, visando à proteção a sua liberdade de crença e sua autonomia como paciente.

A própria legislação vem evoluindo para sagrar a autonomia e vontade do paciente como é o caso do Novo código Civil, a Lei de Transplantes de Órgãos e Tecidos, e o Estatuto do Idoso. Porém, quando se envolve pacientes em condições mais vulneráveis aumenta ainda mais a complexidade desse tema.

Ao paciente que não está no pleno exercício das suas faculdades mentais cabe à família ou ao responsável legal opinar sobre o seu tratamento, ninguém melhor para opinar sobre essa decisão do que um membro da família, considerando que um familiar conhece de modo mais profundo a realidade do paciente, entretanto este familiar deve opinar pelo melhor para o paciente segundo sua perspectiva de vida, e não sobrepor a sua vontade. Considerando esses aportes, vale salientar a importância de deixar registrada a manifestação de vontade no caso de um dia precisar de algum procedimento médico que demande transfusão, no que tange ao aceite ou não desse procedimento.

Quando envolve vida de menor de idade, a autonomia para a escolha do tratamento é outorgada para os pais. A manifestação será dos pais e não do indivíduo, já que este ainda não possui formação completa de seus valores e crenças. A religião muitas vezes ainda não é uma decisão concretizada em pacientes menores de idade e isso deve ser levado em consideração, pois o menor de idade não tem a real noção sobre a problemática e muito menos a consciência de que sua vida está em risco. Em que pese o Estatuto da Criança e do Adolescente diga que os menores têm direito de opinião e expressão, nos casos de transfusão é mais oportuno que essa decisão fique a cabo dos pais, até porque o menor não consegue mensurar os riscos de vida aos quais está exposto. Muitas vezes o corpo médico nesses casos faz intervenções para que ocorra a transfusão com o intuito de salvar a vida desse menor, prevalecendo aqui o direito à vida. Isso ocorre pelo fato da imaturidade do paciente e nesses casos alegam que os pais não podem impor a sua crença em cima de um terceiro, podendo ter a consequência de se perder a vida da criança.

O médico muitas vezes, se vê diante da quebra de seu juramento, o qual visa à vida do seu paciente, a beneficência da saúde deste. Fundamentam que a conduta escolhida visa afastar perigo iminente de vida do paciente, cujo sacrifício ou mal causado, no caso a 
violação da liberdade de crença, é menor do que aquele que se pretende salvar. Ou seja, todo caso deve ser analisado o risco benefício, em casos de eminente perigo de vida a intervenção médica está justificada, quando a escolha feita pelo médico é o único meio de manutenção da vida do paciente. Respaldados pelo próprio Código de Ética Médica o qual rege que o médico deve utilizar todos os meios disponíveis de diagnóstico e tratamento a seu alcance em favor do paciente, e que, intervenção médica ou cirúrgica, sem o consentimento do paciente ou de seu representante legal, se justificada por iminente perigo de vida, contemplando assim o direito à vida.

Como não existe direito absoluto, ou um direito fundamental maior que o outro, cada caso deve ser analisado pontualmente, nos casos nos quais o Judiciário é acionado para decidir ele deve realizar ponderação dos bens em questão e tentar resolver a colisão desses princípios por meio do sacrifício mínimo dos direitos em jogo.

Antes de impor uma transfusão ao paciente o corpo médico e o Judiciário devem analisar se vale a pena "passar por cima" da vontade do paciente e de seus princípios e valores, aniquilando a autonomia do paciente e a sua dignidade como ser humano. Deve-se levar em consideração, também, que além da vida que será protegida, temos o impacto emocional gerado a partir da violação da sua vida social/religiosa. Devemse analisar as consequências de cada decisão e a importância do impacto na vida de cada indivíduo, eis o desafio: a morte biológica ou a morte social?

\section{Referências}

1.World Health Organization. 2006. Disponível em: <http://www.afro.who.int/pt/oms-emafrica/missao-e-funcoes-essenciais.html >. [Acesso em: 25 out 2012].

2.Delduque, MC; Marque,SB. O Direito Social à saúde dever ser garantido por políticas públicas e decisões judiciais. In: Temas atuais de Direito Sanitário. Brasília: Fiocruz, 2009.

3 Mueller, P; Plevak, D; Rummans, T. Religious Involvement, Spirituality and Medicine: Implications for Clinical Practice. In: Mayo Clinic Proceedings. United States: 2001, p. 1225-1235.

5.Dahmani, S. Perioperative blood salvage during surgical correction of craniosynostosis in infants. In: British Journal of Anaesthesia. United States, 2000. 
6.Begliomini, H; Begliomini, B. Técnicas hemoterápicas em cirurgia renal percutânea em paciente testemunha de Jeová. In: Rev. Col. Bras. Cir. Rio de Janeiro: 2005.

7.Junges, JR. Bioética, perspectivas e desafios. São Leopoldo: Editora Unisinos, 1999, p. 322.

8. Lima de Sá, F. A liberdade religiosa e a transfusão de sangue nas testemunhas de Jeová. In: Themis. Fortaleza: 2000.

9.Imbelloni, LE; Beato, L; Ornellas, A; Borges, C. Manuseio de grave diminuição de hemoglobina em paciente jovem, testemunha de Jeová, submetido à proctocolectomia total: relato de caso. In: Revista Brasileira de Anestesiologia. Campinas, 2005.

10.Fitzgerald, RD; Martin, CM; Dietz, GE. Transfusing red blood cells stored in citrate phosphate dextrose adenine-1 for 28 days fails to improve tissue oxygenation in rats. In: Crit Care Med. United States, 1997.

11.Lourenço, K; Lapa, F A transfusão de sangue e as testemunhas de Jeová: conflito ou concorrência de direitos? Trabalho de Graduação (Graduação em Direito) - Universidade Univille, Santa Catarina, 2011.

12.Potter, R. Bioethics -Bridge to the future. Englewood Cliffs: Prentice Hall, 1971.

13. Clotet, J. Bioética uma aproximação. Porto alegre: EDIPUCRS, 2003.

14.Fortes, PA. Bioética, equidade e políticas públicas. Bioética - Uma perspectiva brasileira. In: Mundo da Saúde. São Paulo: 2002, p.143-147.

15.Garrafa, V; Porto, D. Bioética, poder e injustiça: Por uma ética de intervenção. Bioética Uma perspectiva brasileira. In: Mundo da Saúde. São Paulo 2002, p. 6-15.

16.Sims, A. Psyche - Spirit as Well as Mind. In: British Journal of Psychiatry. United States, 1994.

17. Epperly, B. Prayer, process, and the future of medicine. In: Journal of Religion and Health. United States, 2000.

18. Goldim, JR. Bioética: origens e complexidade. In: Revista HCPA. Porto Alegre, 2006, p.86-92.

19.Muriel, C. Aspectos jurídicos das transfusões de sangue. In: Revista dos Tribunais. São Paulo, 1994, p.30-35.

20.Guerra F, WS. Processo Constitucional e Direitos Fundamentais. São Paulo: Celso Bastos Editor - Instituto Brasileiro de Direito Constitucional, 1999.

21.Ferreira,F. M. Questões Constitucionais e legais referentes a tratamento médico sem transfusão de sangue. Parecer. São Paulo: 1994. 
22.Bastos, CR. Direito de recusa de pacientes, de seus familiares ou dependentes, às transfusões de sangue, por razões científicas e convicções religiosas. In: Revista dos Tribunais. São Paulo, 2000.

23.Brasil. Constituição da República Federativa do Brasil de 1988. Disponível em <http://www.planalto.gov.br/ccivil_03/constituicao/constituicao.htm>. [Acesso em 1 de out 2012.]

24.Silva, JA. Curso de direito constitucional positivo. São Paulo: Malheiros, 2000.

25.Pinho, RC. Teoria Geral da Constituição e Direitos Fundamentais - Sinopses Jurídicas. São Paulo: Saraiva, 2000.

26.Sarlet, IW. A eficácia dos direitos fundamentais. Porto Alegre: Livraria do Advogado, 1998.

27.Beauchamp, T; Childress, J. Princípios de ética biomédica. São Paulo: Loyola, 2002.

28.Muñoz, D.; Fortes, PA. O princípio da autonomia e o consentimento livre e esclarecido. In: Costa, S I. F.; Garrafa, V; Oselka, G. Iniciação à bioética. Brasília: Conselho Federal de Medicina, 1998.

29. Brasil. Decreto-Lei no 2.848, de 7 de dezembro de 1940 - Código Penal. Disponível em <http://www.planalto.gov.br/ccivil_03/decreto-lei/del2848.htm>. [Acesso em 28 out 2012.]

30.Conselho Federal de Medicina. Código de Ética Médica. Disponível em: < http://portal.cfm.org.br/index.php?option=com_content\&view=article\&id=20656:codigo-deetica-medica-res-19312009-capitulo-i-principios-fundamentais\&catid=9:codigo-de-eticamedica-atual\&Itemid=122>. [Acesso em 21 out 2012.]

31. Thibes, J. Transfusão de sangue em testemunhas de Jeová x responsabilidade médica. In: Revista de Direito. São Paulo, 2009.

32. Brasil. Lei no 10.406, de 10 de janeiro de 2002 - Código Civil. Disponível em <http://www.planalto.gov.br/ccivil_03/leis/2002/L10406.htm>. [Acesso em 12 nov 2012.]

33. Brasil. Lei $\mathrm{n}^{\circ}$ 8.069, de 13 de julho de 1990 - Estatuto da Criança e do Adolescente. Disponível em <http://www.planalto.gov.br/ccivil_03/leis/L8069.htm.> [Acesso em 15 nov 2012.]

34.Azevedo, Á. Autonomia do paciente e direito de escolha de tratamento médico sem transfusão de sangue. Parecer. São Paulo: Sociedade Torre de Vigia de Bíblias e Tratados, 2010.

35. Brasil. Lei no 10.741, de 1ำ de outubro DE 2003 - Estatuto do Idoso. Disponível em <http://www.planalto.gov.br/ccivil_03/leis/2003/L10.741.htm> . [Acesso em 15 nov 2012.]

36.Vilela, E. A autonomia do paciente em face do Estatuto do Idoso. In: Revista de Previdência Social. São Paulo, 2009. 
Cuadernos Iberomericanos

de Derecho Sanitario

37.Rocha, Ml. Transplantes de órgãos entre vivos: as mazelas da nova lei. In: Revista dos Tribunais. São Paulo, 1977.

38 Brasil. Lei n 10.211, de 23 de março de 2001 - Lei de Transplantes de Órgãos e Tecidos. Disponível em <http://www.planalto.gov.br/ccivil_03/leis/L9434.htm>. [Acesso em 15 nov 2012.]

Recebido em: 5.6.2017

Aprovado em:27.7.2017 